\title{
Unreliable pulse oximetry in dark-skin patients: a plea for algorithm disclosure
}

\author{
Martin J. Tobin * ${ }^{*}$ and Amal Jubran
}

We thank Drs. Ferrari and Scholkmann for their interest in our article [1].

The authors' experience with the accuracy of noninvasive sensors in the face of elevated levels of carboxyhemoglobin and methemoglobin has considerable ramifications for the operation of pulse oximeters. If manufacturers have been able to make modifications-to hardware or software-to enable devices to overcome light-absorbance transmutations consequent to abnormal blood chemistry [2], there is every reason to expect that human ingenuity should be able to solve inaccurate pulse oximetry readings in patients with dark-skin pigmentation [3].

On a purely numerical basis, the problem of unreliable pulse oximetry readings in dark-skin patients is enormously greater than problems arising from abnormal levels of carboxyhemoglobin and methemoglobin. Given that hypoxemia is the lynchpin around which clinical decisions in seriously ill patients with COVID-19 revolve [4], it is imperative that caregivers are alert to the unreliability of pulse oximetry in dark-skin patients [3]. Clinical decisions based on faulty pulse oximetry readings have likely contributed to the several-fold greater number of deaths from COVID-19 in ethnic-minority patients than in white patients [5].

We do not know why manufacturers have invested considerable resources into solving the problems of oximetry in patients with abnormal blood chemistry, but have

This reply refers to the comment available online at https://doi.org/10.1186/ s13613-022-00992-z

*Correspondence: mtobin2@lumc.edu

Division of Pulmonary and Critical Care Medicine, Hines Veterans Affairs

Hospital and Loyola University of Chicago Stritch School of Medicine,

Hines, IL 60141, USA not made comparable endeavors into decrypting the riddle of unreliable pulse oximetry readings in patients of color. The contrasting experiences raise some unsettling questions.

We agree with Drs. Ferrari and Scholkmann that pulse oximetry manufacturers should make public the algorithms employed in their software. With these data, an imaginative investigator-perhaps far removed from the industry-may hopefully hit on a solution to the conundrum of deceptive pulse oximetry readings in patients with dark-skin pigmentation.

\section{Acknowledgements}

Not applicable.

\section{Authors' contributions}

All authors contributed equally to the drafting of the manuscript and provided critical revision for important intellectual content. Both authors read and approved the final manuscript.

Funding

National Institute of Nursing Research (RO1- NR016055).

Availability of data and materials

Not applicable.

\section{Declarations}

Ethics approval and consent to participate Not applicable.

\section{Consent for publication}

Not applicable.

\section{Competing interests}

MJT receives royalties for two books on critical care published by McGraw-Hill, Inc., New York.

Received: 4 February 2022 Accepted: 7 February 2022

Published online: 22 February 2022

\section{Springer Open}

(C) The Author(s) 2022. Open Access This article is licensed under a Creative Commons Attribution 4.0 International License, which permits use, sharing, adaptation, distribution and reproduction in any medium or format, as long as you give appropriate credit to the original author(s) and the source, provide a link to the Creative Commons licence, and indicate if changes were made. The images or other third party material in this article are included in the article's Creative Commons licence, unless indicated otherwise in a credit line to the material. If material is not included in the article's Creative Commons licence and your intended use is not permitted by statutory regulation or exceeds the permitted use, you will need to obtain permission directly from the copyright holder. To view a copy of this licence, visit http://creativecommons.org/licenses/by/4.0/. 


\section{References}

1. Tobin MJ, Jubran A. Pulse oximetry, racial bias and statistical bias. Ann Intensive Care. 2022;12(1):2. https://doi.org/10.1186/s13613-021-00974-7.

2. Kulcke A, Feiner J, Menn I, Holmer A, Hayoz J, Bickler P. The accuracy of pulse spectroscopy for detecting hypoxemia and coexisting methemoglobin or carboxyhemoglobin. Anesth Analg. 2016;122(6):1856-65.

3. Jubran A, Tobin MJ. Reliability of pulse oximetry in titrating supplemental oxygen therapy in ventilator-dependent patients. Chest. 1990;97(6):1420-5.

4. Tobin MJ. Basing respiratory management of COVID-19 on physiological principles. Am J Respir Crit Care Med. 2020;201:1319-20.

5. Acosta AM, Garg S, Pham H, Whitaker M, Anglin O, O'Halloran A, et al. Racial and ethnic disparities in rates of covid-19-associated hospitalization, intensive care unit admission, and in-hospital death in the United States from March 2020 to February 2021. JAMA Netw Open. 2021;4(10): e2130479. https://doi.org/10.1001/jamanetworkopen.2021.30479.

\section{Publisher's Note}

Springer Nature remains neutral with regard to jurisdictional claims in published maps and institutional affiliations.

\section{Submit your manuscript to a SpringerOpen ${ }^{\circ}$ journal and benefit from:}

- Convenient online submission

- Rigorous peer review

- Open access: articles freely available online

- High visibility within the field

- Retaining the copyright to your article

Submit your next manuscript at $\boldsymbol{\nabla}$ springeropen.com 